\title{
Morphea in children: a retrospective study of its clinical characteristics and extracutaneous manifestations
}

\section{Morfea en niños: un estudio retrospectivo de características clínicas y manifestaciones extracutáneas}

\author{
Pamela Rodríguez-Salgado, ${ }^{1}$ Carolina Hernández-Zepeda, ${ }^{2}$ Marimar Saez-de Ocariz, ${ }^{3}$ Marco Antonio Yamazaki- \\ Nakashimada, ${ }^{4}$ María Teresa García-Romero ${ }^{5}$
}

\begin{abstract}
BACKGROUND: Morphea is an inflammatory disease with diffuse thickening and hardening of the skin. It is common in children and it has been reported that as many as $40 \%$ have extracutaneous articular and neurological manifestations, vascular and ocular disorders, and gastrointestinal or respiratory symptoms.

RATIONALE: There are no studies of associated extracutaneous manifestations in Mexican children with morphea.

OBJECTIVE: Describe clinical characteristics, frequency of extracutaneous manifestations, and treatment of pediatric patients with morphea who received care at the Instituto Nacional de Pediatría.

MATERIAL AND METHODS: A retrospective study of patients with morphea, 1 to 18 years of age, who received care between January 1, 2000, and December 31, 2015.

RESULTS: Thirty-two patients with morphea were included, half $(n=16)$ with the linear subtype, followed by plaque-type morphea in 7 (22\%). Extracutaneous manifestations were reported in $23(72 \%)$ patients; the most common were: musculoskeletal in 23 $(72 \%)$, neurological in $9(28 \%)$, and ophthalmological in $3(9 \%)$. Twenty-three patients $(72 \%)$ required systemic treatment. Nineteen patients $(60 \%)$ required orthopedic and surgical treatment for complications. The clinical evolution was toward remission in $72 \%$ of the patients $(n=23)$.

CONCLUSIONS: In this series of 32 cases of children with morphea, $72 \%$ had extracutaneous manifestations, principally musculoskeletal and neurological. It is important to conduct targeted questioning, and if necessary perform paraclinical studies, to identify extracutaneous manifestations which may be associated with morphea, especially when it is linear or extensive.
\end{abstract}

KEY WORDS: Morphea; children; skin; ocular; Mexican; pediatric; linear morphea; ophthalmological.

Resumen

ANTECEDENTES: La morfea es una enfermedad inflamatoria con engrosamiento difuso e induración de la piel. Es frecuente en niños y se ha reportado que incluso $40 \%$ tiene manifestaciones extracutáneas articulares, neurológicas, anormalidades vasculares, afectación ocular, síntomas gastrointestinales o respiratorios.

IUSTIFICACIÓN: No existen estudios de las manifestaciones extracutáneas asociadas en niños mexicanos con morfea.

OBJETIVO: Describir las características clínicas, la frecuencia de las manifestaciones extracutáneas y el tratamiento de pacientes pediátricos con morfea atendidos en el Instituto Nacional de Pediatría.

MATERIAL Y MÉTODOS: Estudio retrospectivo de pacientes con morfea, de 1 a 18 años, atendidos entre el 1 de enero de 2000 y el 31 de diciembre del 2015.

\begin{abstract}
${ }^{1}$ Physician with medical degree from Universidad La Salle. Currently working as a research fellow at the Instituto Nacional de Pediatría, in the dermatology service.

2 Physician with medical degree from Universidad La Salle, resident in Dermatology at Hospital General Dr. Manuel Gea González.

${ }^{3}$ Dermatologist from Hospital General Dr. Manuel Gea González and pediatric dermatologist with degree from the Instituto Nacional de Pediatría, Staff physician at the Instituto Nacional de Pediatría dermatology service.

${ }^{4}$ Pediatric immunologist with degree from the Instituto Nacional de Pediatría, Staff physician at the Instituto Nacional de Pediatría immunology service.

${ }^{5}$ Dermatologist from Hospital General Dr. Manuel Gea González, with a pediatric dermatology degree from the University of Toronto. Master's in Public Health degree from Harvard University. Staff physician at the Instituto Nacional de Pediatría dermatology service.
\end{abstract}

Received: October 25, 2018

Accepted: November 28, 2018

\section{Correspondence}

Maria Teresa García-Romero

teregarro@gmail.com

This article should be cited as Rodríguez-Salgado $\mathrm{P}$, HernándezZepeda C, Saez-de Ocariz M, YamazakiNakashimada MA, García-Romero MT. Morphea in children: a retrospective study of its clinical characteristics and extracutaneous manifestations. Acta Pediatr Mex. 2019:40(2):51-8. 
RESULTADOS: Se incluyeron 32 pacientes con morfea, la mitad $(n=16)$ con el subtipo lineal, seguido de placas en 7 (22\%). En 23 (72\%) pacientes se reportaron manifestaciones extracutáneas, las más comunes fueron: musculoesqueléticas en $23(72 \%)$, neurológicas en 9 (28\%) y oftalmológicas en $3(9 \%)$. Se requirió tratamiento sistémico en 23 pacientes $(72 \%)$. Diecinueve pacientes $(60 \%)$ requirieron tratamiento ortopédico y quirúrgico, por complicaciones. La evolución clínica fue hacia la remisión en $72 \%$ de los pacientes $(n=23)$.

CONCLUSIONES: En esta serie de 32 casos de niños con morfea, $72 \%$ tuvo manifestaciones extracutáneas, sobre todo musculoesqueléticas y neurológicas. Es importante efectuar un interrogatorio dirigido, y si es necesario, estudios paraclínicos para identificar las manifestaciones extracutáneas que pueden asociarse con morfea, especialmente cuando ésta es lineal o extensa.

PALABRAS CLAVE: Morphea; niños; piel; ocular; mexicanos; pediátricos; morfea lineal; oftalmológica.

\section{BACKGROUND}

Morphea, also called localized scleroderma, is a chronic autoimmune disease, of unknown cause, which is clinically defined as an inflammatory disease, primarily of the skin and subcutaneous tissue, in which patients develop sclerosis with diffuse thickening and hardening of the skin. ${ }^{1-5}$ Figure 1

Around $20 \%$ of patients with morphea are children or adolescents, with a mean age of onset at seven years. Linear morphea affects two thirds of patients under 18 years of age; this variant may cause retarded growth of the affected extremity, making proper treatment decisive to prevent asymmetry or permanent functional disability of the extremity. ${ }^{2,3,6}$

Approximately $40 \%$ of children with morphea present extracutaneous manifestations: arthritis, neurological symptoms (headache, seizures), vascular disorders (Raynaud's phenomenon), ocular disorders (uveitis or episcleritis, mainly of the linear variety, in the head or en coup de sabre) and gastrointestinal and respiratory symptoms. The association between location or type of morphea lesions in the skin and the risk of extracutaneous manifestations is unknown, as are risk factors which predispose an individual to its appearance. ${ }^{?}$



Figure 1. Patient with linear morphea in the lower right extremity, with visible sclerosis, changes of pigmentation, and mild atrophy.

The activity of morphea lesions lasts three to five years, with a tendency for improvement, although with residual alterations. In general, more serious, mutilating, and disabling forms are observed in children than in adults..$^{1,2,8,9}$ 
The objective of this study was to describe the clinical characteristics, frequency of extracutaneous manifestations, and treatment of pediatric patients with morphea who received care at the National Institute of Pediatrics.

\section{MATERIALS AND METHODS}

This was a retrospective study of patients with morphea, 1 to 18 years of age, who received care at the National Institute of Pediatrics between January 1, 2000, and December 31, 2015. The search was conducted in the institution's archive of physical and electronic records. Criteria for inclusion were: patients with diagnosis of morphea between 1 and 18 years of age, who received care between January 1, 2000, and December 31,2015 , for whom clinical photographs of lesions were available. Criteria for exclusion were: incomplete records (less than $80 \%$ of the variables to be studied), patients with diagnosis of linear pansclerotic morphea, eosinophilic fasciitis, or systemic sclerosis.

The descriptive statistical analysis was performed in Microsoft Office Excel, version 2017, with measurements of central tendency and dispersion for the quantitative variables and ratios for the qualitative variables.

\section{RESULTS}

Fifty-nine patient files were located and 27 were discarded because they did not meet the criteria for inclusion. Thus, 32 patients with the diagnosis of morphea were included; females predominated, at $69 \%(n=22)$. The linear morphea subtype was the most common, at $50 \%$ (n =16) (Figure 1), followed by plaque morphea at $22 \%(n=7)$ (Figure 2). The median age at initial manifestations was 9 years, with a range of 1 to 16 years. Morphea lesions had characteristics of lichen sclerosus and atrophicus in $41 \%$ ( $n=$ 16) of the cases; deep in $25 \%(n=8)$, and with atrophoderma in $22 \%(n=7)$. Table 1

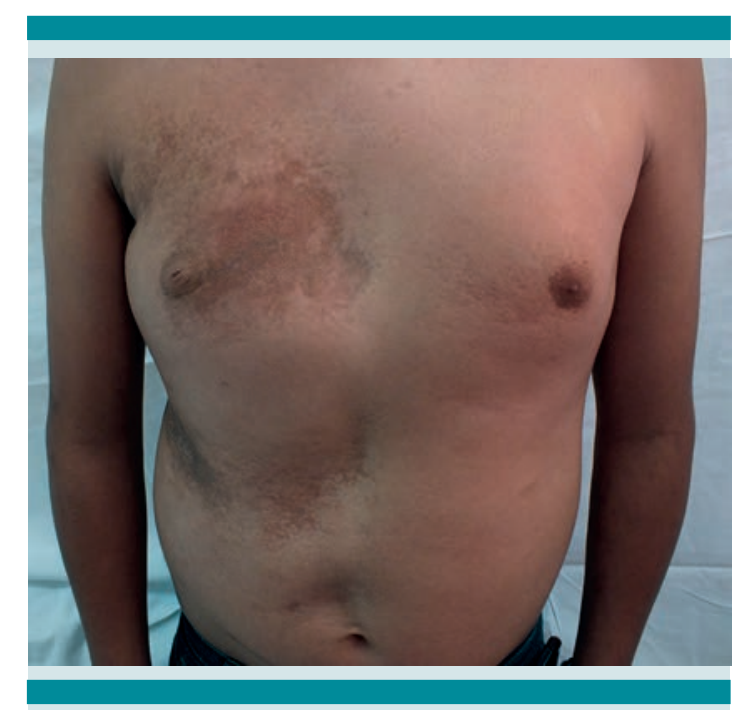

Figure 2. Patient with plaque morphea in the anterior torso, with irregular shaped plaques with dermal atrophy and visible blood vessels.

Table 1. Clinical characteristics of all patients

\begin{tabular}{|lc}
\hline Characteristic & $\mathbf{n}=32$ \\
\hline Age of onset of morphea (median, range) & $\begin{array}{c}9 \\
(1-16 \text { years })\end{array}$ \\
\hline Gender $\mathrm{n}(\%)$ & 22 \\
\hline Female & $(68.75 \%)$ \\
\hline Male & 10 \\
\hline Morphea subtype $\mathrm{n}(\%)$ & $(31.25 \%)$ \\
\hline Linear & \\
\hline Plaque & $16(50 \%)$ \\
\hline Generalized & $7(21.9 \%)$ \\
\hline Mixed & $5(15.6 \%)$ \\
\hline Additional characteristics of morphea $\mathrm{n}(\%)$ & $4(12.5 \%)$ \\
\hline Lichen sclerosus & $13(40.6 \%)$ \\
\hline Deep & $8(25 \%)$ \\
\hline Atrophoderma & $7(21.9 \%)$ \\
\hline None of the above & $10(31.2 \%)$ \\
\hline Clinical evolution $\mathrm{n}(\%)$ & \\
\hline Remission & 23 \\
\hline Activity & $(71.87 \%)$ \\
\hline
\end{tabular}


The diagnosis was clinical in $69 \%$ of patients $(\mathrm{n}=22)$ and skin biopsies were taken from $32 \%$ $(n=10)$. The histological findings reported for morphological changes compatible with morphea were: hyalinization of collagen, collagen entrapment of skin appendages, and superficial and deep inflammatory perivascular infiltrate which may affect the subcutaneous cellular tissue. Figure 3

Extracutaneous manifestations were reported in $84 \%(n=27)$ of patients. The most common were musculoskeletal, with arthralgias predominating



Figure 3. Histopathology of morphea showing thickening and hyalinization of collagen in the dermis, as well as decreased cutaneous appendages.

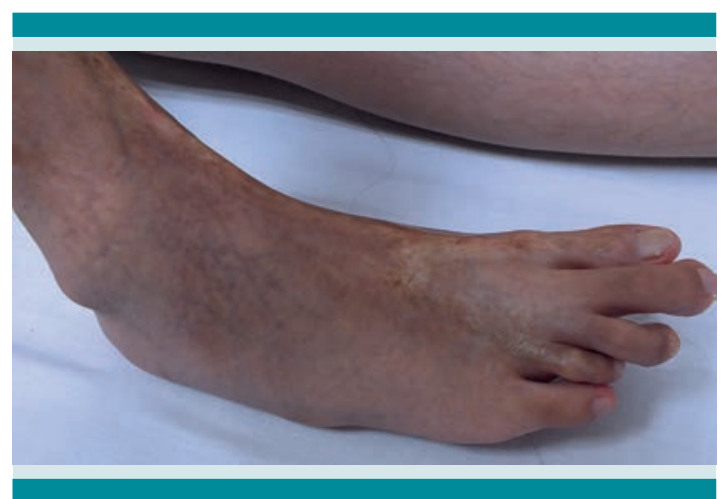

Figure 4. Sclerotic morphea plaque on the right foot, with reduction in length and joint contractures and loss of mobility in the first and fourth toes.
(34\%), and joint contractures (38\%) (Figure 4). Only nine patients $(28.1 \%)$ did not report musculoskeletal manifestations. Twenty-eight percent $(n=9)$ of patients had neurological manifestations; the most common symptom was headache in $22 \%(n=7)$. There was no report of targeted questioning on symptoms for $6 \%$ of the patients and related paraclinical studies were not conducted for $81 \%$. Six patients underwent neurological studies. One patient with linear morphea in the upper left extremity, with seizures underwent: nuclear magnetic resonance (NMR), computed tomography (CT)of the skull, and electroencephalogram (EEG), documenting mild cortical atrophy and epileptic activity. Another patient with linear morphea in the hemiface suffered headaches and underwent a simple CT scan which found osseous atrophy. In most patients there were no reports of ophthalmological manifestations in notes to the clinical file $(78 \%)$, only three patients had clinical alterations: hemihypertrophy, strabismus, exotropia, and keratitis. Table 2

Regarding treatment, the most frequently indicated topical medications were vitamin D analogs, alone or combined with steroids in $22(69 \%)$; and calcineurin inhibitors in 13 patients $(41 \%)$ with circumscribed morphea. In 23 patients $(64 \%)$ with the linear subtype or extensive morphea the most commonly prescribed systemic treatment were systemic steroids as bridge or adjuvant therapy while starting on another drug. The most commonly prescribed immunosuppressants were: methotrexate in $20(62.5 \%)$ of patients, followed by hydroxychloroquine and mycophenolate mofetil. Table 3

As disease activity diminished, the treatment was modified. In the last follow up visit, 12 patients (38\%) continued to use $20 \%$ urea in cream to reduce residual xerosis, 6 patients (19\%) continued receiving methotrexate, and 5 (16\%) hydroxychloroquine as maintenance therapy. 
Table 2. Extracutaneous manifestations in patients with morphea

\begin{tabular}{|c|c|}
\hline Manifestations and studies & $\mathbf{n}=32$ \\
\hline \multicolumn{2}{|l|}{ Musculoskeletal n (\%) } \\
\hline Joint contractures & $12(37.50 \%)$ \\
\hline Arthralgias & $11(34.4 \%)$ \\
\hline Discrepancy in length of extremities & $11(34.4 \%)$ \\
\hline Arthritis & $1(3.12 \%)$ \\
\hline Others & $7(21.87 \%)$ \\
\hline None & $9(28.12 \%)$ \\
\hline Unknown & $1(3.12 \%)$ \\
\hline \multicolumn{2}{|l|}{ Neurological symptoms n (\%) } \\
\hline Headache & $7(21.87 \%)$ \\
\hline Migraine & $1(3.12 \%)$ \\
\hline Seizures & $2(6.5 \%)$ \\
\hline None & $21(65.62 \%)$ \\
\hline Unknown & $2(6.25 \%)$ \\
\hline \multicolumn{2}{|l|}{ Paraclinical neurological tests $\mathbf{n}(\%)$} \\
\hline $\mathrm{CT}$ & $4(12.5 \%)$ \\
\hline EEG & $3(9.37 \%)$ \\
\hline NMR & $1(3.12 \%)$ \\
\hline None & $26(81.25 \%)$ \\
\hline $\begin{array}{l}\text { Results of paraclinical neurological } \\
\text { tests } \mathbf{n}(\%)\end{array}$ & $n=6$ \\
\hline Normal & $1(16.6 \%)$ \\
\hline $\begin{array}{l}\text { Abnormalities incidental or not } \\
\text { related to morphea* }\end{array}$ & $4(66.7 \%)$ \\
\hline $\begin{array}{l}\text { Abnormalities associated with } \\
\text { morphea** }^{*}\end{array}$ & $1(16.6 \%)$ \\
\hline \multicolumn{2}{|l|}{ Ocular manifestations $\mathbf{n}(\%)$} \\
\hline Uveitis & 0 \\
\hline $\begin{array}{l}\text { Others (hemihypertrophy, } \\
\text { strabismus, keratitis) }\end{array}$ & $3(9.37 \%)$ \\
\hline None & $25(78.12 \%)$ \\
\hline Unknown & $4(12.5 \%)$ \\
\hline
\end{tabular}

* A patient with morphea in the upper left extremity also had seizures, and studies (NMR, CT, and EEG) found mild cortical atrophy and epileptogenic rhythm.

** A patient with linear morphea in the hemiface had headaches, and a simple CT scan revealed atrophy of the facial bones on the affected side.
Regarding non-pharmacological treatments, 11 patients $(34 \%)$ received rehabilitation therapy and 8 patients (25\%) surgical treatment by orthopedics (tibia osteotomy with bone lengthening, medial hemiepiphysiodesis of the right knee, plantar capsulotomy, and percutaneous tenotomy of the flexor) and plastic surgery (resection of sclerotic lesion in hairy skin, resection of fatty tissue in the lower lip, implant in the piriform fossa, and multiple lipotransfers). Table 3

Table 3. Treatments received by patients

\begin{tabular}{|c|c|}
\hline Treatment & $\mathrm{n}=32$ \\
\hline \multicolumn{2}{|l|}{ Topical treatment n (\%) } \\
\hline Vitamin D analogs & $22(68.75 \%)$ \\
\hline High-potency topical steroids (class I/II) & $15(46.87 \%)$ \\
\hline Calcineurin inhibitors & $13(40.62 \%)$ \\
\hline $\begin{array}{l}\text { Low-potency topical steroids } \\
\text { (class III/VII) }\end{array}$ & $3(9.37 \%)$ \\
\hline \multicolumn{2}{|l|}{ Others } \\
\hline Pirfenidone & $3(13.64 \%)$ \\
\hline None & $1(3.12 \%)$ \\
\hline \multicolumn{2}{|l|}{ Systemic treatment n (\%) } \\
\hline $\begin{array}{l}\text { Systemic steroids (as bridge-adjuvant } \\
\text { therapy while starting on another } \\
\text { systemic treatment) }\end{array}$ & $23(71.9 \%)$ \\
\hline Methotrexate & $20(62.5 \%)$ \\
\hline Hydroxychloroquine & $11(34.4 \%)$ \\
\hline Mycophenolate mofetil & $7(21.87 \%)$ \\
\hline Oral vitamin D & $2(6.25 \%)$ \\
\hline $\begin{array}{l}\text { Methotrexate and mycophenolate } \\
\text { mofetil combined }\end{array}$ & $1(3.12 \%)$ \\
\hline Systemic steroids (as sole therapy) & 0 \\
\hline NB UVB or UVA1 phototherapy & 0 \\
\hline Others (griseofulvin) & $18(56.25 \%)$ \\
\hline None & $7(21.87 \%)$ \\
\hline $\begin{array}{l}\text { Orthopedic and reconstructive surgical } \\
\text { treatment } \mathrm{n}(\%)\end{array}$ & $8(25 \%)$ \\
\hline Physical rehabilitation n(\%) & $11(34.4 \%)$ \\
\hline
\end{tabular}

$\mathrm{NB} U \mathrm{VB}=$ narrowband ultraviolet $\mathrm{B}$ radiation $(311 \mathrm{~nm})$ UVA1 = ultraviolet-A1 radiation $(340-400 \mathrm{~nm})$ 
The patients' clinical evolution, as reported in the last follow-up visit, was remission with no signs of activity in 23 patients ( $72 \%$ ) and active disease in $4(12 \%)$ with new lesions and $2(6 \%)$ with reactivation of old lesions.

\section{DISCUSSION}

Morphea is an uncommon disease which often appears in childhood. In this cohort of 32 patients at the National Institute of Pediatrics, the most relevant findings were: predominance of female gender $(69 \%)$, which is related to previous reports in the literature, where the female to male ratio is $2.6: 1 .^{1,2}$ The most common subtype in the patients studied was linear (50\%), which also coincides with global experience. ${ }^{4,7,9}$ In this study, the age range was 1 to 16 years with mean age of nine years, similar to that reported in the bibliography with mean age at onset of seven years. ${ }^{2,6,8}$

In literature reports, almost $50 \%$ of patients with the linear subtype also have plaque morphea (mixed morphea, common in children). ${ }^{1,2,3,4,8,10,11}$ In our study, only $13 \%$ of patients had the mixed subtype of morphea.

In the most relevant published series of patients with morphea, around $40 \%$ of children with the disease had extracutaneous manifestations. , $^{72-16}$ Of our 32 patients, 27 (84\%) had some extracutaneous manifestation related to morphea. Linear morphea retards growth of the affected extremity, and causes joint contractures. ${ }^{2,6,8}$ In our series of cases, the most common manifestations were musculoskeletal, with predominance of arthralgias (34\%), discrepancy in length of extremities (34\%), and joint contractures (38\%). Neurological manifestations are more common when morphea affects the head, and there are even structural alterations; in our study there were nine patients $(28 \%)$ with headaches, migraine, or seizures. ${ }^{17}$ Only three patients had ophthalmological disorders, and although uveitis is the most commonly associated with morphea, none of them presented it. In many of our patients, information for targeted questioning to check for extracutaneous manifestations, mainly neurological and ophthalmological, was not available; as a result of which their real frequency may be underestimated.

The choice of treatment should depend on the subtype and extension of morphea. Based on clinical guidelines and consensus, ${ }^{18-22}$ morphea which can potentially cause functional disability or deformity (like the linear subtype in the head or extremities in children) requires systemic treatment; and topical treatment is suitable for the other subtypes. In our study, the most widely prescribed topical medicines were: vitamin D analogs (69\%), calcineurin inhibitors (41\%), and high-potency topical steroids (47\%). Although there are few clinical trials with a high degree of evidence, today calcineurin inhibitors and vitamin D analogs are the safest, most effective drugs. ${ }^{2,3,10,13}$ Topical steroids should be prescribed with caution in patients with morphea because they may help reduce swelling in active superficial lesions but may have little or no effect in treating sclerosis and could potentially cause greater atrophy. ${ }^{2,4}$

Regarding systemic treatment, immunosuppression with systemic corticosteroids (methylprednisolone $1-2 \mathrm{mg} / \mathrm{kg} /$ day or prednisone $0.5-1 \mathrm{mg} / \mathrm{kg} /$ day) is useful in inflammatory stages of morphea, above all in patients with rapidly progressive or disabling linear morphea. Methotrexate in doses of 15-20 mg weekly (dose $10-15 \mathrm{mg} / \mathrm{m}^{2}$ of body surface) is currently the recommended first-line treatment for the active phase of morphea, with or without adjuvant use of systemic corticosteroids. 2,5,10,13 Mycophenolate mofetil is another well tolerated immunosuppressant which has been effective in children 
with morphea who have not had a successful response to treatment with a combination of glucocorticoids and methotrexate..$^{10}$ The systemic treatment most commonly prescribed in our cohort was systemic steroids as bridge or adjuvant therapy while starting on another systemic treatment $(72 \%)$ : methotrexate in $63 \%$, followed by hydroxychloroquine in $34 \%$ of the patients, and mycophenolate mofetil in $23 \%$.

Other treatments available include UVA1 phototherapy, currently the treatment of choice for deep lesions because it alters the course of the disease inducing expression of metalloproteinase; ${ }^{1}$ a collagenase which reduces procollagen and collagen in the skin, with complete relief or noticeable improvement in at least $60-80 \%$ of patients. ${ }^{2,4}$ Less effective is UVB phototherapy. The National Institute of Pediatrics does not have phototherapy facilities, for which reason none of the patients received such treatment.

A limitation of this study was finding incomplete information in medical notes, which potentially prevented us from estimating the real frequency of extracutaneous manifestations (there is no way to know if the patients actually did not have certain extracutaneous manifestations, did not undergo targeted questioning, or the information was not entered in the notes).

Nevertheless, this study is the first to describe clinical characteristics and extracutaneous manifestations in Mexican children with morphea. We found a higher incidence of the linear subtype in our patients compared with the findings reported in the bibliography, and a lower incidence of the mixed subtype. A highly relevant finding in this cohort of patients is that a very high percentage had musculoskeletal and neurological alterations related to morphea. Targeted questioning and paraclinical studies to identify extracutaneous manifestations (neurological and ophthalmological alterations) was not done routinely, and thus, underreporting is likely.

\section{CONCLUSIONS}

Morphea is an uncommon disease, which often appears in childhood and predominates in females. The linear subtype is common and is associated with more musculoskeletal extracutaneous manifestations. These were reported in $84 \%$ of our patients: musculoskeletal alterations occurred in 69\%, neurological disorders in $28 \%$, and ophthalmological disorders in $9 \%$, although the frequency of the latter two may be underestimated in our study.

As areas of opportunity for the future, we consider it important to apply targeted questioning to patients with morphea regarding the most common extracutaneous manifestations, and when they are suspected confirm them by means of paraclinical studies. Also, it is crucial to improve the amount and quality of information in medical records, in order to obtain the most complete information from retrospective studies such as this one, and strengthen our understanding of the disease and patients' medical care.

\section{REFERENCIAS}

1. Yu BD, Eisen AZ. Scleroderma. In: Freedberg IM, Eisen AZ, Wolff $K$, et al. ed. Fitzpatrick's Dermatology in general medicine, vol II. 6ta edición. Nueva York, EEUU: McGrawHill, 2003: 1709-1717.

2. Röcken M, Ghoreschi K. Morphea and Lichen Sclerosus. In: Bolognia J, Jorizzo J, Rapini R. ed. Dermatology. 2a ed. España: Mosby Elsevier; 2008: 1469-1476.

3. Weibel L, Harper J. Morphea (Localized Scleroderma). In: Irvine A, Hoeger PH, Yan AC. Ed. Harper's textbook of pediatric dermatology. 3ra ed. NJ: Wiley-Blackwell. 2011: 1651-58.

4. Careta M, Romiti R. Localized scleroderma: clinical spectrum and therapeutic update. Anais Brasileiros de Dermatologia. 2015;90(1): 62-73.

5. García de la Peña, P. Esclerodermia localizada. Protoc diagn ter pediatr. 2014;1:10: 1-6.

6. Behman R, Kliegman R, Jenson H, Agud Aparicio J. ed. Nelson, tratado de pediatría. 2a ed. Madrid: McGraw-Hill, 2002: 765-766.

7. Garcia-Romero MT, Laxer R, Pope E. Localized Scleroderma: Symptoms, Diagnosis and Treatment. In: De Winter, R. ed. 
Scleroderma. Symptoms, Diagnosis and Treatment. NY: Nova Science Publishers, Inc, 2013: 87-103.

8. Arenas R. Dermatología. Atlas, diagnóstico y tratamiento. 4a ed. México: McGraw-Hill; 2015, pag 169-174.

9. Alfaro Cordero, K. Morfea: El desequilibrio entre la producción y la destrucción del colágeno. Revista médica de Costa Rica y Centroamérica LXXIII. 2016; 619: 351-354.

10. Bielsa Marsol, I. Update on the Classification and Treatment of Localized Scleroderma. Actas Dermo-Sifiliográficas (English Edition). 2013;104(8): 654-666.

11. Warner Dharamsi J, Victor S, Aguwa N, et al. Morphea in Adults and Children Cohort III. JAMA Dermatology. 2013; 149(10): 1159.

12. Christen-Zaech S, Hakin MD, Afsar FS, Paller AS. Pediatric morphea (localized scleroderma): Review of 136 patients. J Am Acad. Dermatol. 2008; 59:385-96.

13. Noguera M, Sauro de Carvalho M, Lombardi V. Morfea. Arch. Argent. Dermatol. 2012;62: 77-84.

14. Atzeni F, Bardoni A, Cutolo M et al. Localized and systemic forms of scleroderma in adults and children. Clin Exp Rheumatol. 2006; 24 (suppl.40):S36-45

15. Zulian F, Vallongo C, Woo P, et al. Localized scleroderma in childhood is not just a skin disease. Arthritis Rheum. 2005; 52: 2873-81
16. Pequet MS, Holland KE, Zhao S, et al. Risk factors for morphoea disease severity: A retrospective review of 114 pediatric patients. Br J Dermatol. 2014; 170(4): 895-900.

17. Chiu YV, Vora S, Kwon EK, Maheshwari M. A significant proportion of children with morphoea en coup de sabre and Parry-Romberg syndrome have neuroimaging findings. Pediatr Dermatol. 2012; 29(6):738-48.

18. Uziel Y, Feldman BM, Krafchik BR, Yeung RS, Laxer RM. Methotrexate and corticosteroids therapy for pediatric localized scleroderma. J Pediatr. 2000; 136: 91-95.

19. Weibel L, Sampaio MC, Visentin MT, et al. Evaluation of methotrexate and corticosteroids for the treatment of localized scleroderma (morphoea) in children. $\mathrm{Br} J$ Dermatol. 2006; 155(5):1013-20.

20. Kreuter A, Altmeyer P, Gambichler T. Treatment of localized scleroderma depends on the clinical subtype. British Journal of Dermatology. 2007; 156(6): 1363-1364.

21. Bielsa Marsol, I. Update on the Classification and Treatment of Localized Scleroderma. Actas Dermo-Sifiliográficas (English Edition). 2013; 104(8), 654-666.

22. Martini G, Campus $S$, Bernd $R$, et al. Tocilizumab in two children with pansclerotic morphoea: a hopeful therapy for refractory cases? Clin Exp Rheumatol. 2017; 35 Suppl 106(4):211-213. Epub 2017 Sep 29. PMID: 28980909 